\title{
炭素繊維補強モルタルの水分容量，透湿率及び表面係数の推定 STUDY ON WATER CAPACITY, MOISTURE PERMEABILITY AND SURFACE FACTER OF CARBON FIBER REINFORCED MORTAR
}

\author{
永松静也*，大常 好範** \\ Seiki NAGAMATSU and Yoshinori OTSUNE
}

\begin{abstract}
The constants of specific water capacity $\alpha$, moisture permeability $\lambda$ and surface factor $f$ are included in a partial differential equation, representing the moisture movement in cement-based materials and its boundary condition. Therefore, they must be made clear to analyze the moisture movement.

In this paper, the following two series of experiments were made to obtain them for carbon fiber reinforced mortar. ( Series 1 - the measurement of $\alpha$ )

Written in a differential form as $\alpha=\mathrm{dWe} / \mathrm{dh}$ (We : evaporable water, $\mathrm{h}$ : relative humidity), $\alpha$ was obtained from measuring $\mathbf{h}-$ We relationship.

(Series 2 -the evaluations of $\lambda$ and $f$ )

The evaluations of $\lambda$ and $f$ were made by means of the inverse operation, fitting the measured values of $t-W d$ relationship with the calculated ones.
\end{abstract}

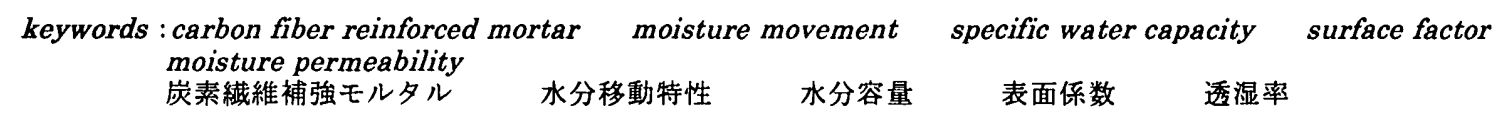

\section{1.はじめに}

炭素繊維補強モルタル(CF RM) は乾燥収縮ひびわれが発生し難 い材料であるとされている。このような材料を適切に使用するため には、他の材料に比べてどの程度乾燥収縮ひびわれが発生し難いの かを評価すること、更には何がどのようなメカニズムでひび割れ発 生を抑制しているのかを明らかにすることが大事である。これにつ いては、図 1 に示す流れ図に従って研究を進める予定である。 本論文は、このような研究の一環として C F R Mの水分の移動を解 析する上で必要とされる材料定数を測定、もしくは推定することを

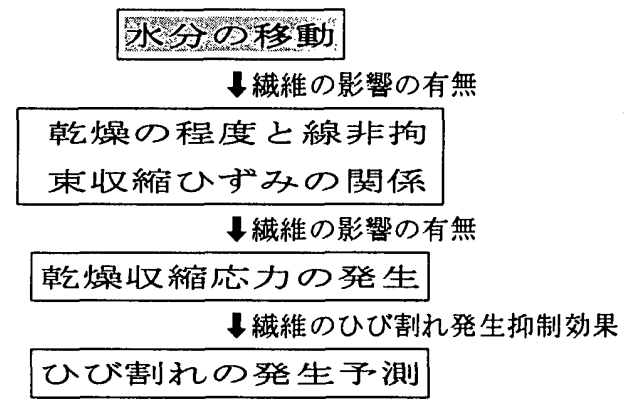

図 1 ひび割れ発生予測までの流れ図
試みたものである。供試体の水分の移動を表す偏微分方程式及び境 界条件の中には、水分容量、透湿率及び表面係数の 3 つの定数が含 まれる。従って、供試体中の水分の移動を解析寸るためにはこれら の定数が明らかにされていなければならない。

水分容量 $\alpha$ は $\alpha=\mathrm{dWe} / \mathrm{dh}$ で表せる（Weはある湿度下で残存す る蒸発可能水量を、hは相対湿度を表す)。そこで水分容量 $\alpha$ は、 $\mathrm{h}$ 一We関係を得ることにより求められる。これについては多くの研 究者が基䃈データとして求めているが、その殆どが供試体を一度、 絶乾状態にした、いわゆる吸着曲線として得られている。本論文で は処女乾燥過程における $\mathrm{h}-\mathrm{We}$ 曲線を対象としている。

透湿率入の測定は実験的に大変難しいが、考えられる方法とし て、以下の方法があげられる。

1) 湿流移動が定常状態にある供試体中の湿度勾配と湿流量を測定 し、 $\lambda$ を算出する方法。一直接的な算出法 ${ }^{12}{ }^{21}$

2) 乾燥する供試体の脱水量の経時変化の測定值と計算值を合わせ ることにより逆算する方法。一間接的な算出法 ${ }^{3}$

1)の方法は供試体と空気との境界層の取り扱いが難しく、若材令 の場合も含めて、多くの実験要因に対応するのが困難である。2)の 方法は間接的な方法であるが、測定そのものは簡単である。よって、 本論文では、2）の方法によった。

\footnotetext{
* 大分大学工学部建設工学科 教授 $\cdot$ 工博

**大阪ガス珠材料技術プロジェクト部 工修

(大分大学大学院工学研究科 博士後期課程学生)
} 
表面係数 $\mathrm{f}$ は供試体の置かれている環境条件に大きく左右される がここでは実駼室内を対象としている。測定方法は透湿率の測定と 同じ方法をとった。ここでは、薄板状の供試体の乾燥時間一脱水賭

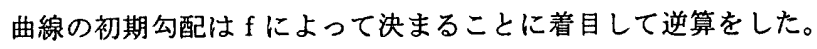
な拉、これらの係数は温度に大きく依存するが、本実験では $20^{\circ} \mathrm{C} 一$

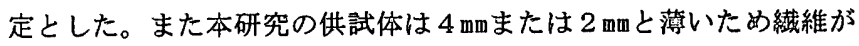
2 次元に近い状態で配向しているものを扱っている。供試体が厚く なった場合については次の課題とする。

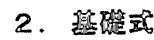

図 2 のように板の厚さ方向に（一次元）水分が移動する場合を取 り扱う。物体内の単位面積を単位時間あたりに移動する水分量 q は (1)式のように表せる。

$$
\begin{aligned}
& q=-\lambda \frac{\partial h}{\partial s} \\
& \text { ただし、 } q \text { : 流束 } \\
& \lambda: \text { 透湿係数 } \\
& \text { h: 試片内の相対湿度（試片内の含有水分量と平衡 } \\
& \text { する相対湿度） } \\
& \frac{d h}{d s} \text { : 湿度勾配 s : 水分の移動方向にとった座標 }
\end{aligned}
$$

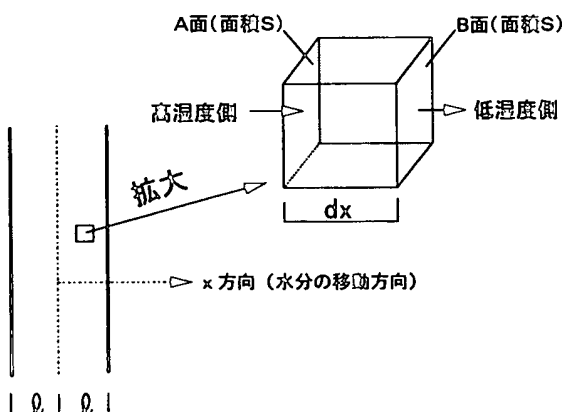

図 2 試片断面(左) と断面内の微小直 6 面体（右）

今、微少時間 $\mathrm{dt}$ 間に、図 2 の微小6面体 $\mathrm{A}$ 面から流入する水分量は

$$
W_{A}=-\lambda \frac{\partial h}{\partial s} S d t
$$

B面から流出する水分量は、

$$
W_{B}=-\left\{\lambda \frac{\partial h}{\partial x}+\frac{\partial}{\partial s}\left(\lambda \frac{\partial h}{\partial s}\right) d x\right\} S d t
$$

となり、微小 6 面体中の蒸発可能水量の変化は次のように表せる。

$$
d W e S d x=\frac{\partial}{\partial x}\left(\lambda \frac{\partial h}{\partial x}\right) d x S d t
$$

ここで、Heは単位容樌当たりの蒸発可能水量を表す。いま、Weの変 化による相対湿度の変化を(5)式で表すと (4) 式より、相対湿度hに

a $d h=d W e$

関する偏微分方程式が次のように得られる。

$$
\alpha \frac{\partial h}{\partial t}=\frac{\partial}{\partial s}\left(\lambda \frac{\partial h}{\partial s}\right)
$$

ここで、水分容量 $\alpha$ および透湿率入は試片の材龄（水和度）や乾燥 の程度などに依存するため(6)式は非線形となる。

<境界条件 $>$
試片の表面から大気中へ蒸発する水分量は次式で表せる。

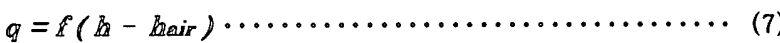

ここで、f は表面係数，hairは外気の相対湿度である。

以上より、(6)式を解くためには $\alpha, \mathrm{f}, \lambda$ のつの材料定数を決定 しなければならないことが分かる。

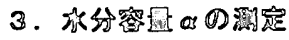

3-1.鼠醫

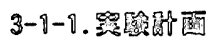

各種相対湿度平衡下におけるC F R M の蒸発可能水量を測定し、 We一h関係を得るために以下の実験を計画した。

乾燃開始材龄：1，7，28日試験体数：各 3 体

\begin{tabular}{|c|c|c|c|c|c|c|c|}
\hline 調合 & $\mathrm{CF}$ & \multirow{2}{*}{$\begin{array}{l}\text { W/C } \\
(\%)\end{array}$} & \multirow{2}{*}{$\begin{array}{l}\text { S/C } \\
(\%)\end{array}$} & \multicolumn{3}{|c|}{ 缶量 $\left(\mathrm{kg} / \mathrm{m}^{3}\right)$} & \multirow{2}{*}{ 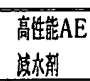 } \\
\hline 锤疑 & (vol.\%) & & & w & $\mathrm{C}$ & $\mathrm{s}$ & \\
\hline (1) & 1.0 & \multirow{3}{*}{47.0} & \multirow{3}{*}{0.5} & 4457 & 970 & 485 & \multirow{3}{*}{ Cx1. or } \\
\hline ת & 2.0 & & & 452 & 961 & 480 & \\
\hline (3) & 0.0 & & & 462 & 980 & 490 & \\
\hline
\end{tabular}

設定相対湿度：20，45，66，86，100\%

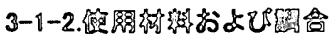

使用材料を以下に、調合表を表 1 にそれぞれ示す。 セメト：早強ボ 以ランドセメト（秋父小野田セメント社製, 比重3.14）

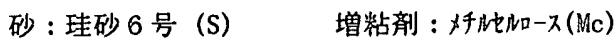

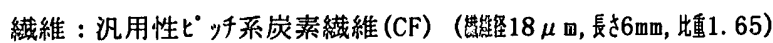

\begin{tabular}{|c|c|c|}
\hline 30移周空暴》 & 3分周藏り混世゙ & 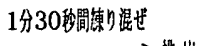 \\
\hline & 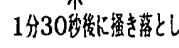 & 1分後炇导落とし \\
\hline
\end{tabular}

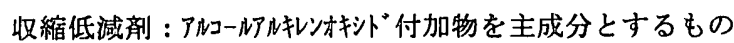
高性能AE澄水剤：ボ师ボン酸を主成分とするもの

表 1 C F RMの調合表

※McをCFのマトリクスへの分散を考虽して、調合(2)ではセメン $2 \mathrm{~kg}$ に対し $10 \mathrm{~g}$, 調合(1), (3)では $2 \mathrm{~kg} に$ 対し $5 \mathrm{~g}$ の割合で外割混入

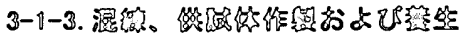

CFがモルタルマトリクスによく分散するように、ホバートミキ サーにより以下に示すような手順で練り混ぜた。

練り混ぜの終了したモルタルを $4 \times 0.4 \times 14 \mathrm{~cm}$ の成形体になるよう に12連鋼製型杂に気泡が残らないよう配滤しながら詰めた。つぎに、 モルタかからの水分蒸発を防ぐために、打設面 $(0.4 \times 14 \mathrm{~cm})$ を真䤼板、ビ ニールデーフ、パラフ仿でシールした。24時間後、予め余盛りしておいたモルタ 部分をサハトヘ・ーパ付きグラインダで除去し、脱型後直ちにサランラップ、アル

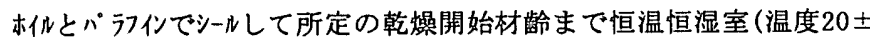
$2^{\circ} \mathrm{C}$, 湿度 $60 \pm 2 \%$ )でシー意生した。

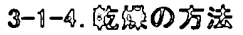

供試体の乾燥には、幅 $287 \times$ 高さ $487 \times$ 奥行 $290 \mathrm{~mm}$ の立方体デシケータを 用いた。図3に示すように供試体を乾燥を阻害しないように十分な 間隔を保ってデシケータ内に静置し、調湿剂とKOH過飽和水溶液を同封し た。使用した調湿剂と湿度の測定值を表 2 に示寸。KOH過飽和水溶液 はデシケータ内の炭酸がスを除去するために用いた。シール養生中の供試体 は湿度 $100 \%$ と仮定した（湿度が、ほぼ100\%であることを別途確認し 
ている)。なお、デシケータの保存や測定は全て恒温恒湿室内で行った。

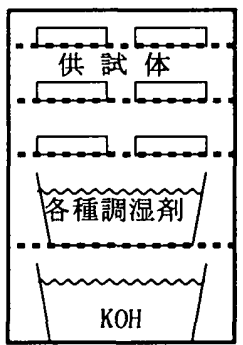

図 3 デシケータ概略図
表 2 調湿剤の種類と測定值

\begin{tabular}{|l||c|c|c|c|}
\hline \multicolumn{1}{|c||}{} & 理論值 & \multicolumn{3}{c|}{ 湿度測定值( \%) } \\
\hline 調湿剂 & $(\%)$ & 1 日 & 7 日 & 28 日 \\
\hline $\mathrm{KHS}_{4}$ & 86 & 80.8 & 79.0 & 79.0 \\
\hline $\mathrm{NaNO}_{2}$ & 66 & 66.7 & 66.2 & 66.2 \\
\hline $\mathrm{KNO}_{2}$ & 45 & 49.1 & 48.4 & 48.4 \\
\hline $\mathrm{CH}_{3} \mathrm{COOK}$ & 20 & 25.4 & 18.8 & 18.8 \\
\hline
\end{tabular}

※湿度測定には比汭”ククスYH-12-P2

（精度 $\pm 2 \%(15 \sim 85 \%)$ 増田理化工業(㧔)

を使用

\section{3-1-5. 質量の測定}

質量椡定 (精度0.1mgの電子天科を使用)のフローを以下に示す。

. (質量測定フロー)

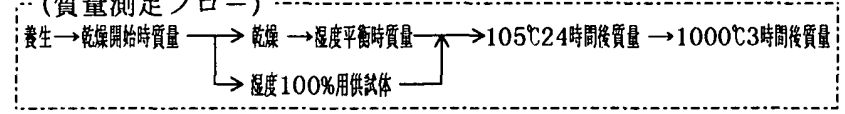

※供試体質量が変化しなくなった時点を湿度平衡時質量とし、

シケータから取り出して $105^{\circ} \mathrm{C} て ゙$ 乾燥後、微粉砕して強熱减量した。

\section{3-2. 実験結果}

測定結果を表 3 およ゙図 4 に示す。また、これらの結果からh-We 関係を図示すると図 5 のようになる。ここで、内は供試体の相対湿度 で、デシケーター内の相対湿度と平衡しているものとする。

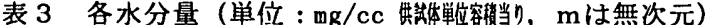

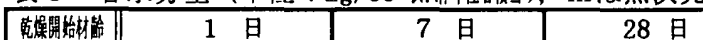

\begin{tabular}{|l|l|l|l|l|l|l|l|l|l|}
\hline 临合No. & (1) & (2) & (3) & (1) & (2) & (3) & (1) & (2) & (3) \\
\hline
\end{tabular}

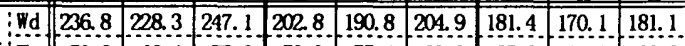

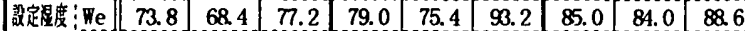

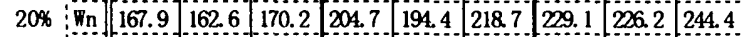

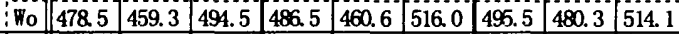

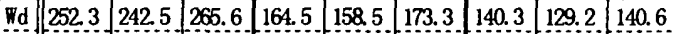

䚺定应度

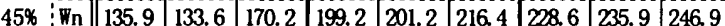

\begin{tabular}{l|l|l|l|l|l|l|l|l|l|l}
\hline To & 473.2 & 456.2 & 494.5 & 470.5 & 464.2 & 503.8 & 492.5 & 486.5 & 513.2 \\
\hline
\end{tabular}

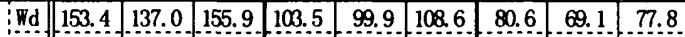

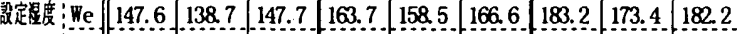

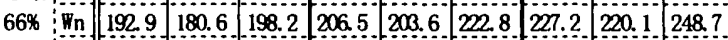

\begin{tabular}{|l|l|l|l|l|l|l|l|l|l|}
\hline Wo & 493.9 & 456.3 & 501.8 & 473.7 & 4620 & 498.0 & 491.0 & 462.6 & 508.7 \\
\hline
\end{tabular}

\begin{tabular}{l|l|l|l|l|l|l|l|l|l} 
Nd & 97.4 & 92.4 & 104.3 & 50.6 & 521 & 56.0 & 29.3 & 25.9 & 27.4 \\
\hline
\end{tabular}

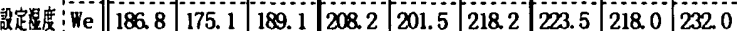

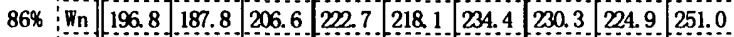
\begin{tabular}{|l|l|l|l|l|l|l|l|l|l|l}
\hline W & 481.0 & 455.3 & 500.0 & 481.5 & 471.7 & 508.6 & 483.1 & 468.8 & 510.4 \\
\hline
\end{tabular}

Wd - - - - - - - - - - - - - - -

設定甠度 $\begin{array}{llllllllllll}100 \% & W_{n} & 125.8 & 115.2 & 131.6 & 220.0 & 220.9 & 240.9 & 248.6 & 239.0 & 262.7\end{array}$

\begin{tabular}{|l|l|l|l|l|l|l|l|l|l|l|l|l|l|l|l|l}
\hline Wo & 474.0 & 457.3 & 492.5 & 494.6 & 486.4 & 525.9 & 511.7 & 485.7 & 527.9 \\
\hline
\end{tabular}

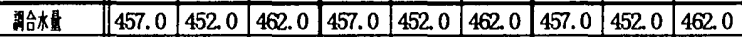

\begin{tabular}{|l|l|l|l|l|l|l|l|l|l|}
\hline $\mathrm{m}$ & 0.506 & 0.482 & 0.501 & 0.885 & 0.924 & 0.917 & 1.0 & 1.0 & 1.0 \\
\hline
\end{tabular}

$W o:$ 全水量 $(=W d+W e+W n)$

$W n:$ 結合水量 $\left(1000^{\circ} \mathrm{C} て ゙ 3\right.$ 時間乾燥したときの減量)

$W d$ : 脱水量（一定の温度及び相対湿度にあるデシケータ内で 9 週間乾燥したときの減量)

$W e$ : 蒸発可能水 $\left(105^{\circ} \mathrm{C} て ゙ 24\right.$ 時間乾燥したときの減量)

調合水量 : 練り混ぜ時の水量

$\mathbf{m}:$ 水和度 $=$ その時点での結合水量Wn 水和が終了した時点での結合水量Wn舟

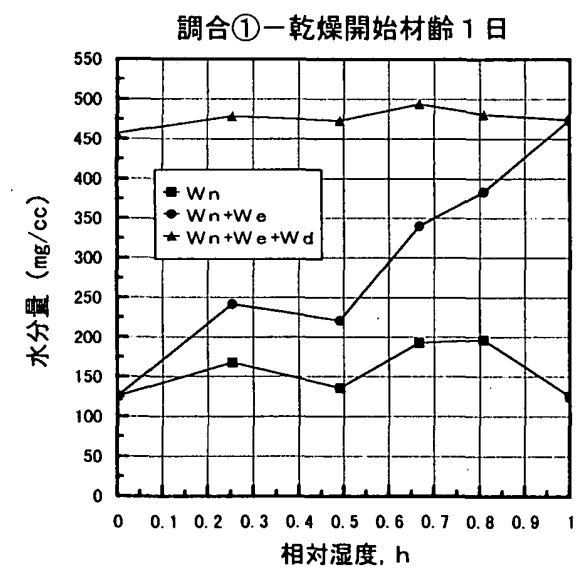

铜合(1)一乾燥開始材魿 7 日

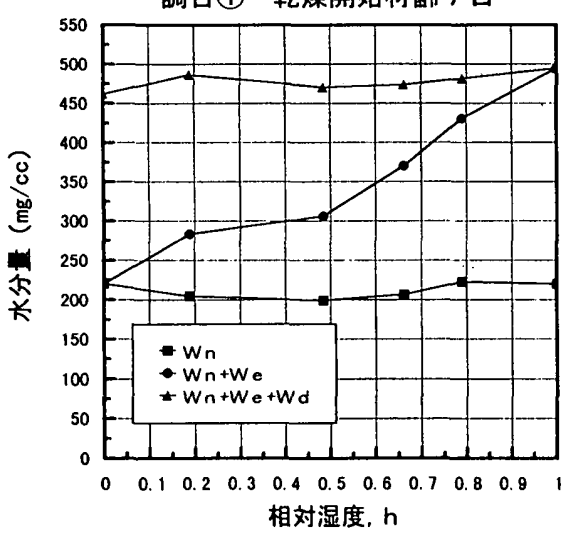

調合(2)一乾燥開始材龄 1 日

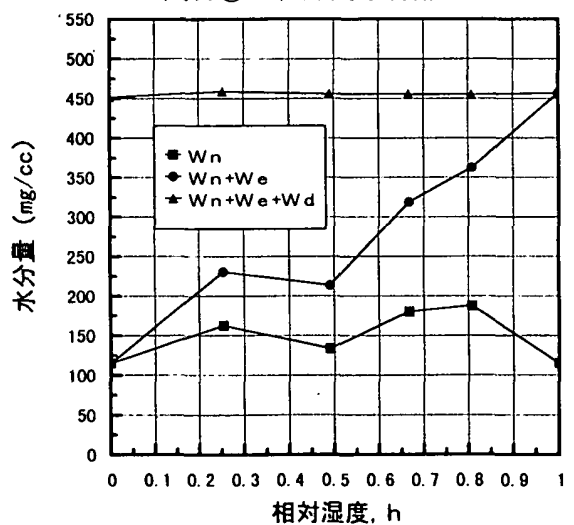

調合(2)一乾燥開始材榷 7 日

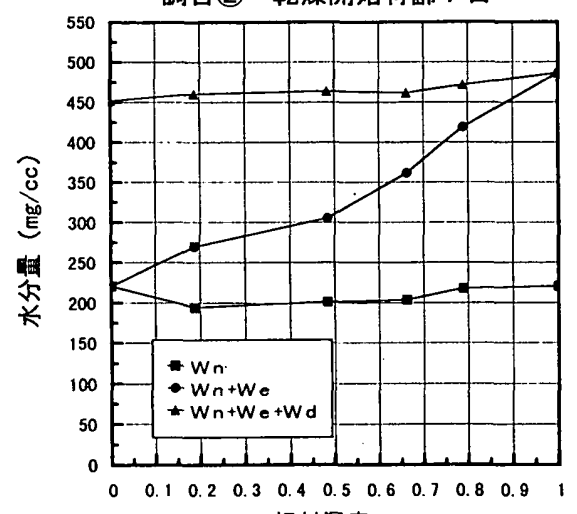

相対湿度, h
調合(3)一乾燥開始材歯 1 日

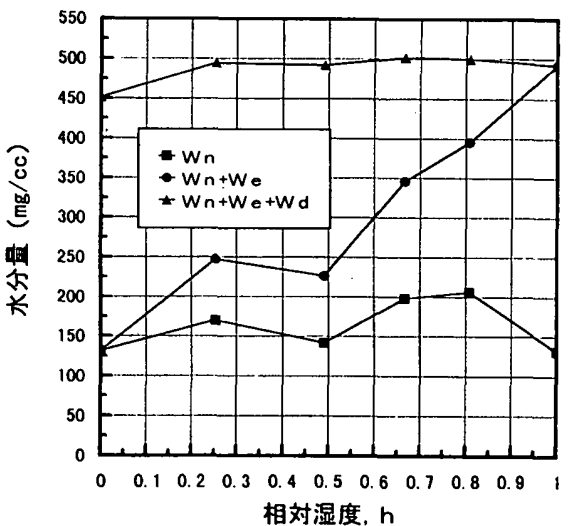

調合(3)一乾嬠開始材路 7 日

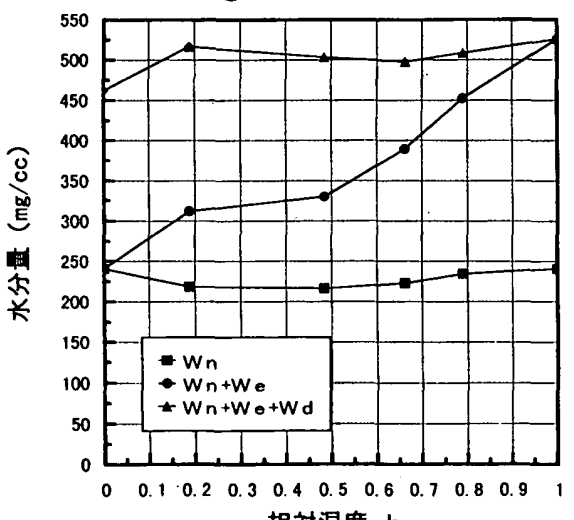

相対湿度, h 

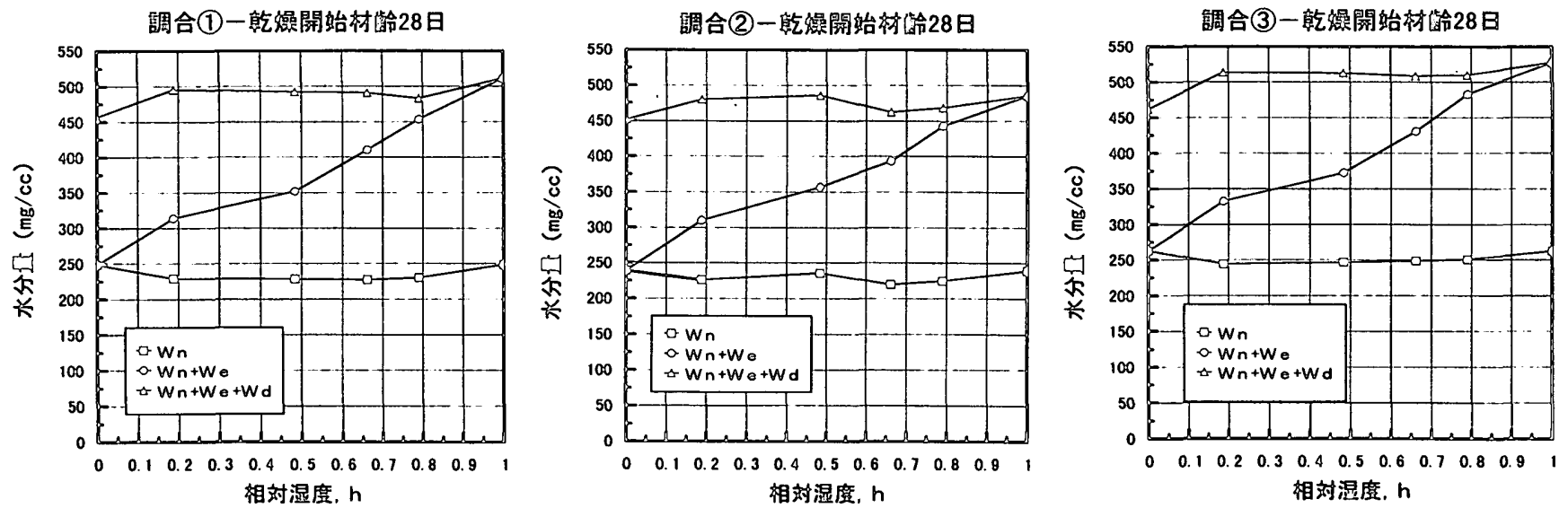

図 4 相対湿度と各水分量の関係
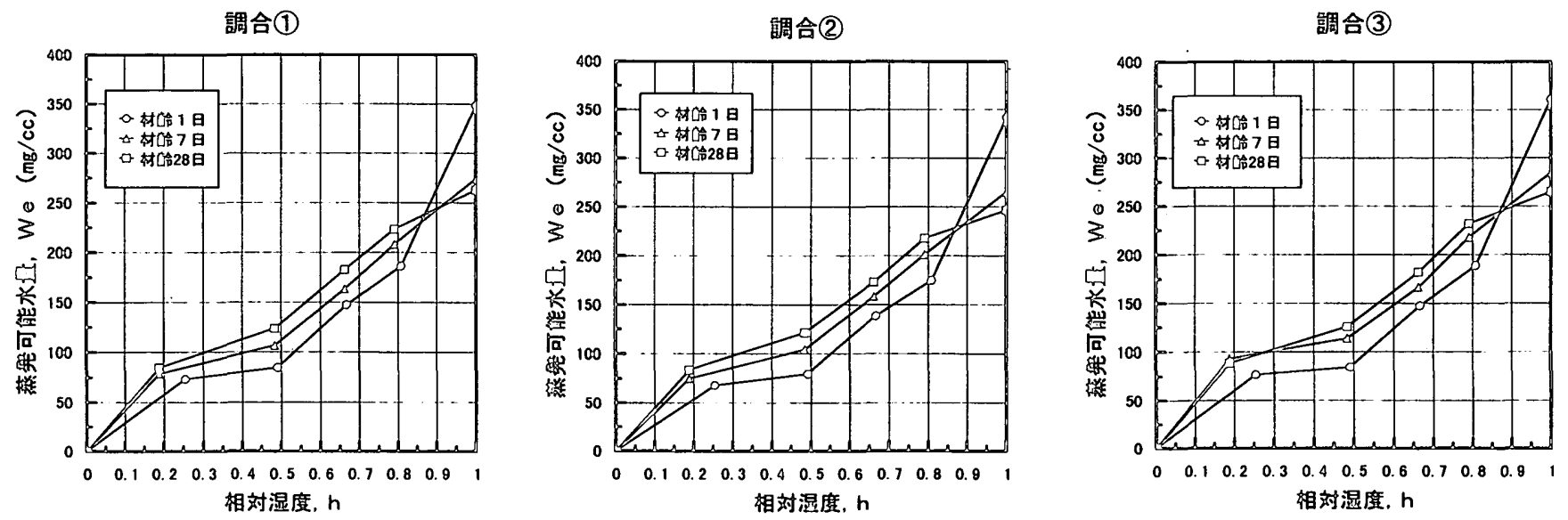

図 $5 \mathrm{~h}-\mathrm{W}$ e 関係

これらの図から、h一We関係は、ほぼー形をしていることがわかる。 材齢の影響をみると、相対湿度hに対応する蒸発可能水量睡は材龄が 若いほど小さいことがわかる。しかし、高湿度域では材淽が若いほ ど勾配が急であり、当然ながら、h=1.0（湿度 $100 \%$ ）における蒸発
可能水は材龄が若いほど多いため曲線は逆転することがわかる。こ の傾向は著者らによるセメントペーストについての測定例“) と一 致 している。この测定結界を各材齢毎に $\mathrm{h}=1.0$ における蒸発可能水Weo で正規化すると図 6 のようになる。
調合(1)

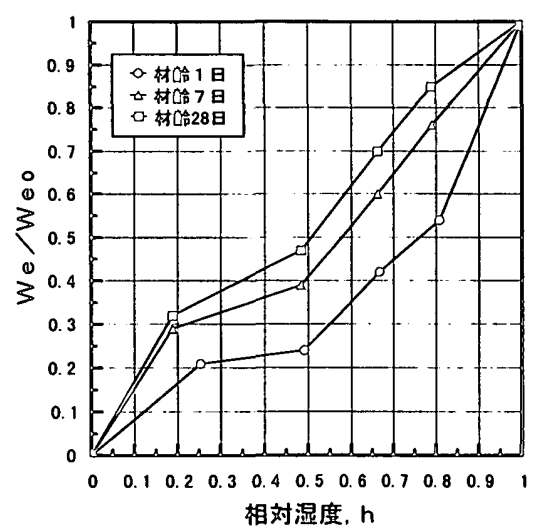

調合(2)

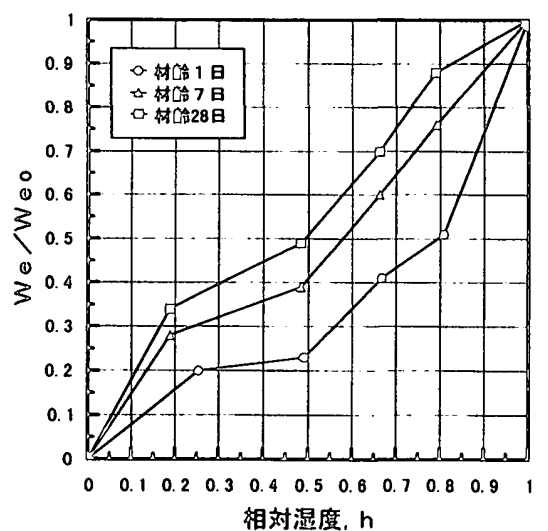

図 $6 \mathrm{~h}-\mathrm{We} / \mathrm{We}$ 。関係
調合(3)

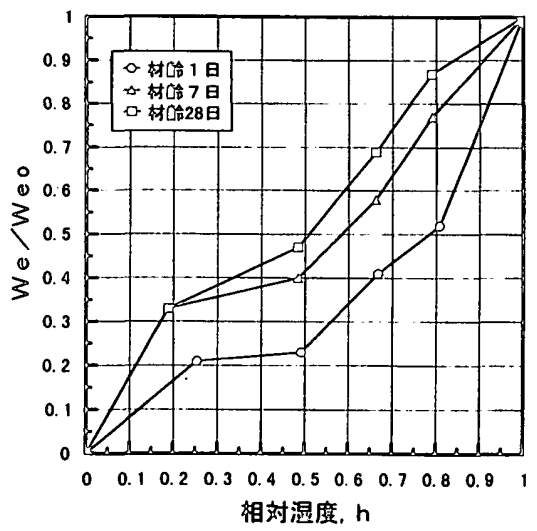




\section{3-3. $\mathrm{h}$-We/Woo曲線の数式表示}

図 6 より、h一We/Weo曲線はかなり複雑で、これを忠実に数式化 するのは困難である。ここでは、中高湿度域のみを対象とし、次式 のような指数関数式で表すことにした。

$$
\begin{gathered}
\frac{W e}{W e o}=h^{\beta} \ldots \ldots \ldots \ldots \ldots \ldots \ldots \ldots \ldots \ldots \ldots \ldots \ldots \ldots \\
W e o: \text { 米乾燥時の蒸発可能水量 }(=W o-W n) \\
\beta .: \text { 材齢 (水和の程度) によって決まる定数 }
\end{gathered}
$$

ここでは、Weo, $\beta$ を水和度 $\mathrm{m}$ で表す。本実験では早強セメントを使 用していることから、材齢28日の結合水量をWnœとみなした（m， Wo, Wnœの值については表 3 を参照)。

また、Weoは次式のように表せる。

$W e o=W o-W n_{\infty} m$

Wo，Wnについて見てみると調合による差は見られない。

(8)式の $\beta$ については、実測データに合うように試行錯誤により求 めた。その結果を図 7 に示す。
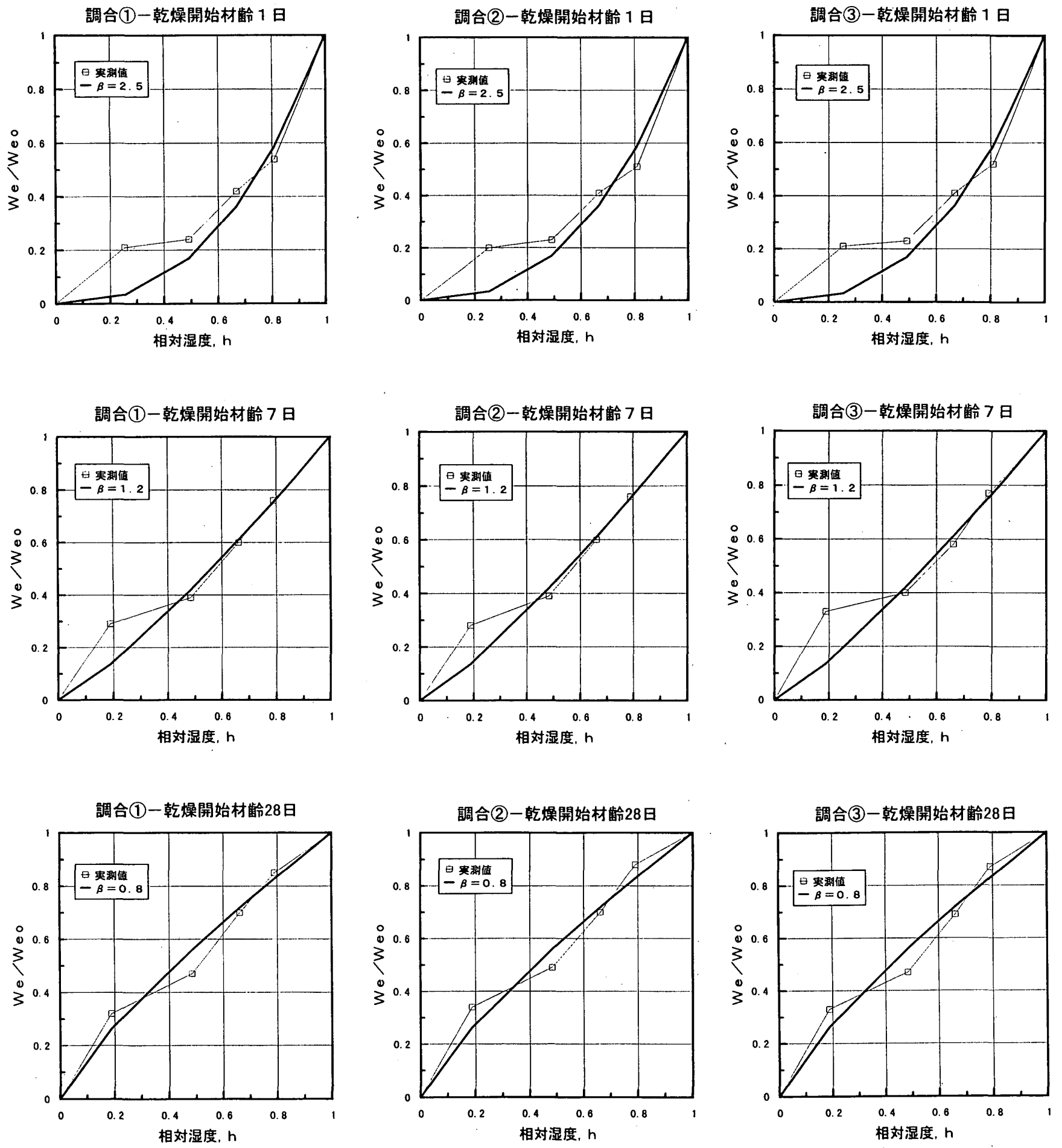

図 $7 \quad \beta$ の推定 
これらの場合の $\beta$ と $\mathrm{m}$ の関係を示すと図 8 のようになる。

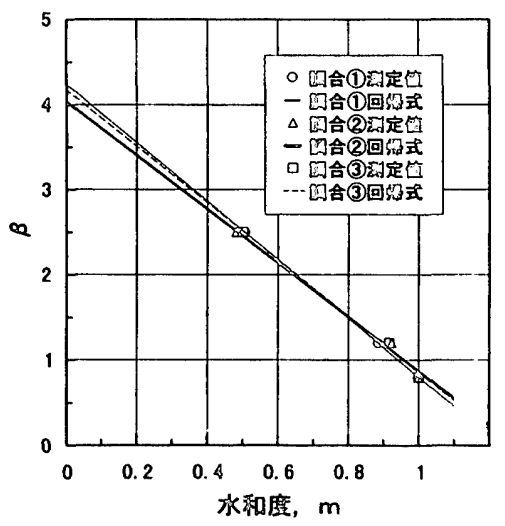

図 $8 m-\beta$ の関係

調合による差はほとんどみられない。そこでこれらをまとめ表せば 次式のようになる。

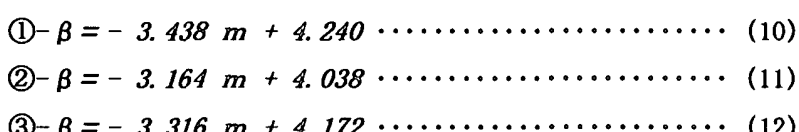

(3) $-\beta=-3.316 m+4.172 \ldots \ldots \ldots \ldots \ldots \ldots \ldots \ldots \ldots$ (12)

3-4. \&について

以上の結果から、本実験の場合の $\alpha$ は次のように与えられる。

$\alpha=\frac{d W e}{d h}=$ Weo $\beta b^{\beta-1}$

$\mathrm{m}$ が与えられると等は (9) 式より、 $\beta$ は (10)〜 (12) 式より得られる。

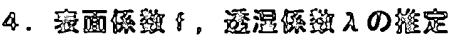

ごく薄い、厚さ $2 m m$ の薄片供試体の乾燥による脱水量のデータを用 いf， $\lambda$ を推定する。これにより、脱水は速やかに終結し、乾燳途 中の水和の進行による影響が小さくなる。ここでは(6)式を2mmの薄 片の境界条件のもとで、線形および非線形として解き、これに実測 データをあてはめ $\mathrm{f} ， \lambda$ を以下のように逆算することを試みる。

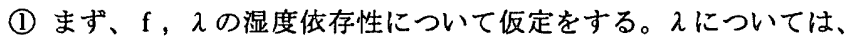
拡散係数についてBazantの提案した式 ${ }^{5}$ を透湿率に換算した式 を用いる。 $\mathrm{C}=\lambda / \alpha$ (C:拡散係数) より $\mathrm{C} / \mathrm{C}_{0}=(\alpha 0 / \alpha)\left(\lambda / \lambda_{0}\right)$

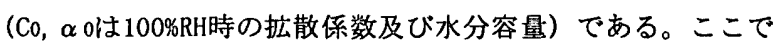
(13) 式より $\alpha 0 / \alpha=1 / \mathrm{h}^{\beta-1}$ となる。従って以下の式を得る。 $\lambda=\lambda o h^{\beta-1}\left\{a_{0}+\frac{1-a_{0}}{1+\left(\frac{1-h}{1-b c}\right)^{n}}\right\}$

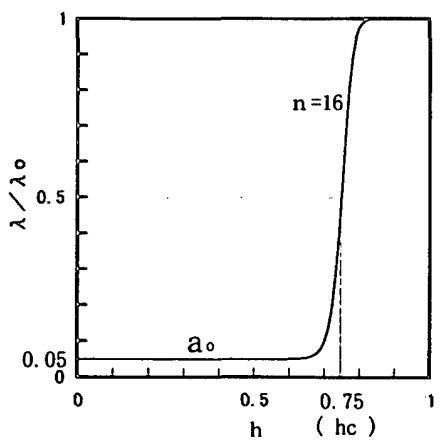

図 $9 \mathrm{~h}-\lambda / \lambda \mathrm{o}$ 関係
なお \{ \} 内の式は、 $\mathrm{C} / \mathrm{C} 0$ についてBazantの提案し た式である。ここで、入。 は供試体の相対湿度が 100\%の時の透湿率，hは 供試体の相対湿度, a 。 hc, n は図 9 に示すよう な意味を持ち、その決定 にあたっては立献5)の表 1より a $。=0.05, h c=0.75$, $n=16$ とした。 fについては次の二つのケースを仮定する。

Case $1 ： \mathrm{~h}$ に依存せず一定とする $(\mathrm{f}=\mathrm{fo})$ 。この場合、境界層が 乾燥と共に短くなる。

Case 2 : 依存性が(14)式で表せるとする。ただし $\lambda ， \lambda$ oをそれ ぞれ $\mathrm{f}, \mathrm{f}$ oに置き換える。境界層の長さは一定となる。 ここで、f oは供試体の相対湿度hが100\%の時の表面係数。

(2) 上述した(1)の仮定により、 $\mathrm{fo}, \lambda \mathrm{o} / \mathrm{f}$ oを決める問題に帰着さ れる。このため炊の二つの条件を与える。

(a) 実測值と計算值の「時間一脱水量曲線」の初期勾配を合わせる

（b）実測値と計算值の「時間一脱水量曲線」を合わせる

(a)は乾㰒開始直後のため線形とみなせ解析解が利用できる。こ れにより後述するように、与えられた $\lambda \mathrm{o} / \mathrm{f} \circ$ oのもとで、 $\mathrm{f} o$ が 简単に求的られる。

(b)は乾燥が進んでいるため非線形となる。そこで、(6)式をFEM を用いて解き、脱水量の実測データに合わせ、最適な $\lambda \circ / \mathrm{fo}$ を決定する。

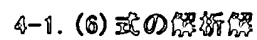

(6)式において、h を h - hairに变換して解く。 境界条件：的＝0において

$$
\frac{d(h-h a i r)}{d s}=0
$$

$$
\begin{aligned}
& x=B \text { において } \\
& \frac{d(h-h \text { air })}{d s}=-\frac{f}{\lambda}(h-h \text { air })
\end{aligned}
$$

初期条件 : $\mathrm{t}=0$ において

$$
\text { h- hair = I- hair }
$$

これらの条件より(6)式の解は次のようになる。

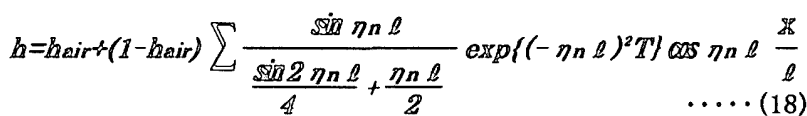

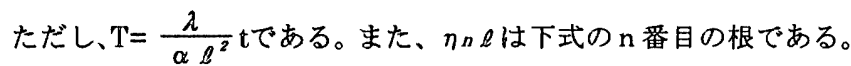

$$
\eta \mathscr{L}=\frac{1}{\eta \ell} \cdot \frac{\ell \mathscr{E}}{\lambda}
$$

\section{<脱水雷 $>$}

供試体表面より単位時間, 単位面穓当り外気中に流れる水分量 q は、

$$
q=\left\{\left(1-h_{a i r}\right) \sum \frac{\sin \eta_{n} \ell}{\frac{\sin 2 \eta_{n} \ell}{\mathbb{L}}+\frac{\eta_{n} \ell}{2}} \exp \left\{\left(-\eta_{n} \ell\right)^{2} T\right\} \cos \eta_{n \ell}\right.
$$

となり、時刻 $\mathrm{t}$ における脱水量Wdは(21) 式のようになる。

$$
\begin{aligned}
& W Q^{d}=\frac{a \mathscr{C} \ell^{2}}{2}\left(1-h_{\text {air }}\right) \sum \frac{\sin \eta_{n} \ell \cdot \cos \eta_{n} \ell}{\frac{\sin 2 \eta_{n} \ell}{4}+\frac{\eta_{n} \ell}{2}} \cdot \frac{1}{\left(\eta_{n} \ell\right)^{3}} \\
& x\left\{1-\exp \left((-\pi n \mathscr{L})^{2} \mathbb{T}\right)\right\}
\end{aligned}
$$

次に、（20)式における $\mathrm{t}-\mathbb{d}_{\mathrm{d}}$ 曲線の $\mathrm{t}=0$ における傾き $g_{t=0}$ は (22) 式の ようになる。 
$q_{t=0}=f\left(1-h_{\text {air }}\right) \quad \sum \frac{\sin \eta_{n} \ell \cdot \cos \eta_{n \ell}}{\frac{\sin 2 \eta_{n} \ell}{4}+\frac{\eta_{n} \ell}{2}}$

\section{4-2. (6) 式の非楾形解}

一次元F.E. M.による。

4-3. $f \circ, \lambda \circ$ 推定方法

(1) まず、 $\mathrm{t}$-Wd曲線の実測值より初期勾配 q oを求める。

(2)（22）式における $\Sigma$ の項を1.0として ${ }^{* 11} \mathrm{f}$ 。の第一次近似 $\overline{\mathrm{f}}$ oを次 式より求める。

$$
\overline{f o}=\frac{q_{o}}{1-\text { hair }}
$$

(3) $\mathrm{f} o=\overline{\mathrm{f}}$ oとし、FEMによる脱水量の計算值と実測值が合うように 繰り返し計算し、最適の $\lambda \mathrm{o} / \mathrm{fo}$ 。求める。得られた $\lambda \mathrm{o} / \mathrm{fo}$ より次式から foを修正する。

$$
f o=\frac{f o}{\sum \frac{\sin \eta_{n} \ell \cdot \cos \eta_{n \ell}}{\frac{\sin 2 \eta_{n \ell}}{4}+\frac{\eta_{n \ell}}{2}}} \cdots \cdots \cdots \cdots \cdots \cdots \cdots(24)
$$

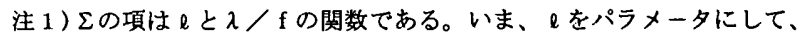

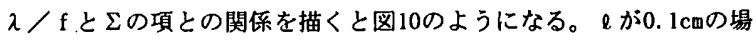

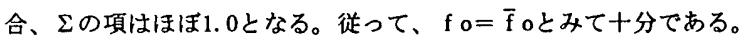

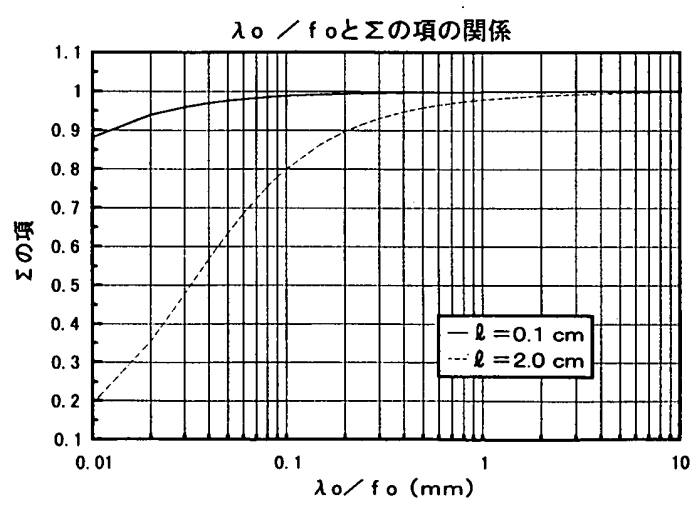

図10（22）式における $\Sigma$ 項の計算値

\section{4-4. 実験}

\section{4-4-1. 実鉑計画}

厚さ $2 \mathrm{~mm}$ の薄片供試体により脱水量の経時変化を測定する。実験要因 としては、供試体の乾嬠開始材齢、外気の相対湿度とする。なお、 温度は一定 $\left(20^{\circ} \mathrm{C}\right)$ とする。

- 乾燥開始材齢 : 1, 7, 28日

-外気の設定相対湿度 : $60 \%$ ・供試体数 : 各 3 体

\section{4-4-2. 使用材料および铜合}

$3-1-2$ に同じ

\section{4-4-3. 混練、供試体作製および養生}

$3-1-3$ に同じ

\section{4-4-4. 乾嬠の方法}

供試体からの蒸発水分によって周边の湿度（hairに相当）が影響
を受けないようなキャバシデ持つ恒温恒湿室にて乾燥を行った。

\section{4-4-5. 貫昷の測定}

質量の測定には精度0.1mgの電子天秤を用いた。なお、乾燥直後の 質量減少率は著しいので、この変化に十分、追随出来るような測定 間隔で供試体質量を測定した。

\section{4-5. 实験の䊅果およひ考察}

\section{4-5-1. 時間一脱水関係およひその初期勾尽}

図11に時間一脱水量関係の測定值を示す。これをもとに、初期勾 配を求めた。しかし、この值は外気の相対湿度hairに依存するため、 (23)式で定義した的（ みてよい)で表すことにした。その結果が表 4 に示されている。これ によると、繊維混入の影響は見られない。材令の影響を平均值で見 ると材路 1 日で0.2876、7 日で0.2313、28日で0.0973 $/ \mathrm{cm}^{2}$ dayとなっ て材路が大きいほど小さくなっている。

表 4
f foの測定值 (単位 : $\mathrm{g} / \mathrm{cm}^{2}$ day)
\begin{tabular}{|c||c|c|c|}
\hline 材齡 & $(1)$ & $(2)$ & $(3)$ \\
\hline 1 日 & 0.2755 & 0.2743 & 0.3131 \\
\hline 7 日 & 0.2372 & 0.2382 & 0.2184 \\
\hline 28 日 & 0.1009 & 0.0951 & 0.0959 \\
\hline
\end{tabular}

\section{4-5-2. $\lambda \circ / f \circ の$ 逆推定}

4-3に示す手順に従ってfo、入。を逆算した。FEMの計算において材 料定数は以下のようにした。即ち、 $\alpha$ の值は 3 章の実験值を、 $\overline{\mathrm{f}}$ 。は 4 章の実験值を用いた。 $\lambda$ の湿度依存性には（14）式を、 $\mathrm{f}$ の湿度依存 性については前述したCase1及びCase2の二通りとした。 $\lambda$ o/foにつ いてはこれをパラメータとして、 $\mathrm{t}-\mathbb{W d}$ 関係の計算を繰り返し実測データ と最も合致する場合の值を搜し出した。Case1の場合は、Case2に比べ て、計算值を実測值に合わせるのが困難であった。Case2の場合につ いて、脱水量の計算值と実測值を比較すると図11のようになる 22 。 これによると材齢 7 日、28日は全体的によく一致している。材齡 1 日 については乾燥初期はよく一致しているが中盤において、 $\mathrm{t}$-Wd曲線 の曲率が一致していない。材齢 1 日の場合、自由水が多いために水 分移動沖必ずしも(6)式に従わないことが考えられる。

fo、 $\lambda$ oの推定結果 (Case2のみの場合) を表 5 に示す。これによると

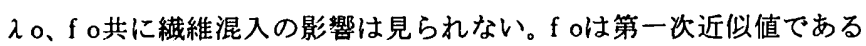
$\overline{\mathrm{f}}$ 。とほぼ変わらない。入 齢1日で0.2878、7日で0.0234、28日で0.0092 $/ \mathrm{cmday}$ となり材跉が大 きくなるにつれ桁のオーダーで小さくなっている。参考のため既往の 測定値と比較してみると、文献2)では直接法により、供試体厚さ1m m, 95\%RH, 砂セメント比40\%において、0.0015g/cm dayを得ている。本

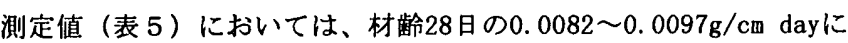
対応するが、本測定值の方が約 8 倍大きい。これは本実験の測定が first dryingであること、乾燥収縮低減剤を使用していること、水 セメント比が $47 \%$ と大きいことなどによるものと思われる。次に、 $\lambda \circ / \mathrm{f}$ oは、材莑 1 日で $1.0 \mathrm{~cm}, 7$ 日で0. $1 \mathrm{~cm}, 28$ 日で $0.08 \sim 0.1 \mathrm{~cm}$ となった。

注 2） $\mathrm{t}$-Wd曲線の終局值の大きさは $\alpha$ に依存するにここでは実測値と計算值 を合わせるため $\alpha$ を調整することはしていない）が曲率は入。／foに 依存する。 

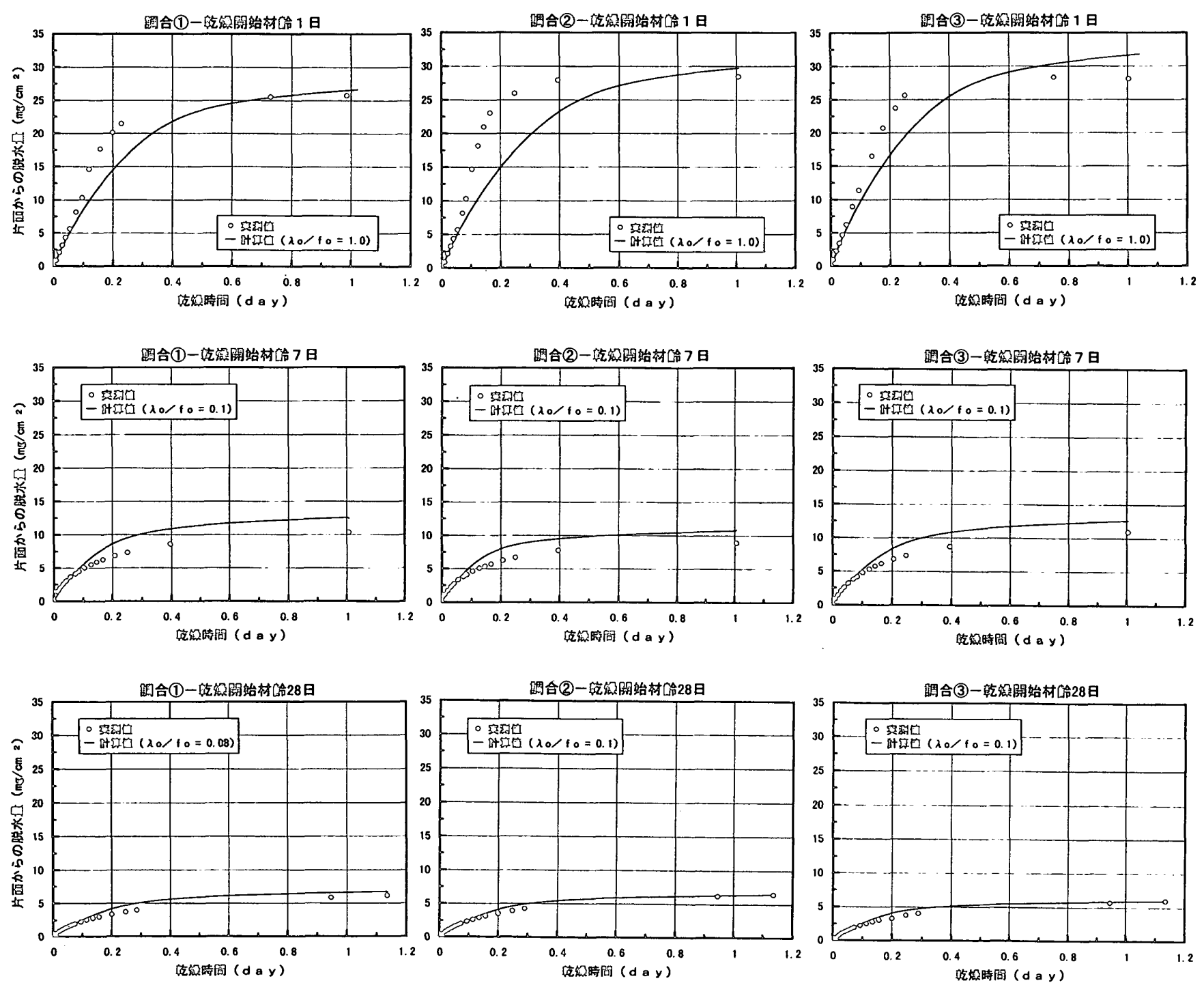

図11乾焒時間一脱水量関係

表 $5 \lambda$ o及び $\mathrm{f}$ oの推定值

\begin{tabular}{|c|c|c|c|c|c|}
\hline 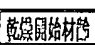 & 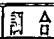 & इの項 & $\lambda \mathrm{o} / \mathrm{fo}(\mathrm{cm})$ & $\lambda \circ(\mathrm{g} / \mathrm{cm}$ day $)$ & f o (g/culd clay $)$ \\
\hline \multirow{3}{*}{1 日 } & (1) & 0.9990 & 1.0 & 0.2758 & 0.2758 \\
\hline & (2) & 0.9988 & 1.0 & 0.2746 & 0.2746 \\
\hline & (3) & 0.9989 & 1.0 & 0.3131 & 0.3131 \\
\hline \multirow{3}{*}{7 日 } & (1) & 0.9860 & 0.1 & 0.0241 & 0.2406 \\
\hline & (2) & 0.9880 & 0.1 & 0.0241 & 0.2411 \\
\hline & (3) & 0.9864 & 0.1 & 0.0221 & 0.2214 \\
\hline \multirow{3}{*}{ 28日 } & (1) & 0.9854 & 0.08 & 0.0082 & 0.1024 \\
\hline & (2) & 0.9880 & 0.1 & 0.0096 & 0.0963 \\
\hline & (3) & 0.9900 & 0.1 & 0.0097 & 0.0969 \\
\hline
\end{tabular}

5. 䇴踻

以上の実験、解析による簕囲内で以下のことがわかった。

1） $\mathrm{h}-\mathrm{We} / \mathrm{Weo}$ 曲線は中高湿度域に限定すれば指数関数式で表

せ、指数は水和度の関数となる。本実験では指数は材龄1日で 2.5 材齢7日で1.2、材齢28日で0.8となり調合による影鄂は見ら

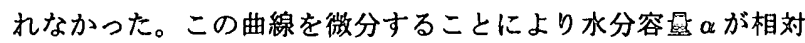
湿度 $\mathrm{h}$ の関数として得られる。

2 ）薄板状の供試体の場合、 $\mathrm{t}-\mathrm{Wd}$ 曲線の初期勾配から表面係数 foが求まることを示した。f oは繊維の混入による影響を受け なかった。材齢の影響を平均值で見ると材龄1日で0.2878g/ $\mathrm{cm}^{2} \mathrm{day}$ 、

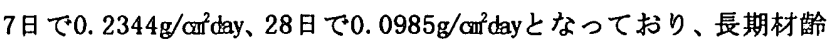
ほど小さくなっている。

3) $\mathbf{t}-W d$ 曲線の実測值にFEMによる解析值を合わせることにより 入。を逆算した。これによると入。は瀻維混入の影薌を受けなかっ た。また材龄の影響を平均值で見ると、材齢 1 日で $0.2878 \mathrm{~g} / \mathrm{cmday} 、$ 材齢 7 日で0. 0234g/cmday、28日で0. 0092g/cmdayとなって、材龄 が大きくなるにつれ街のオーダーで小さくなっている。 $\lambda \circ / \mathrm{fo}$ は材齡 1 日で $1.0 \mathrm{~cm} 、 7$ 日で $0.1 \mathrm{~cm} 、 28$ 日で $0.08 〜 0.10 \mathrm{~cm}$ となった。

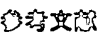

1）西岡, 原田：コンクリートの透湿率及び湿気拡散率について：七゙忮術年報, pp. 274 278, 昭和36年

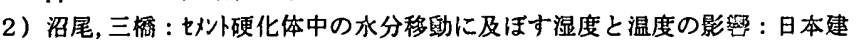

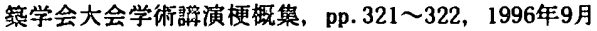

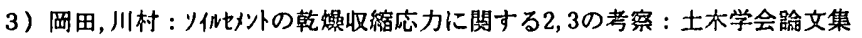
第142号, pp. 37 45, 1967年

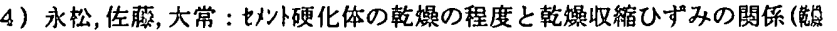

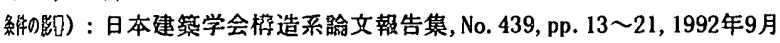

$5)$ Z.P. BAZANT, L. J. NAJJAR:Non 1 inear vater diffusion in nonsaturated concrete, Materials and Structures, Vol.5, pp. 3 20, 1972年

（1997年 9 月22日原稿受理，1998年 3 月 3 日採用決定） 